\title{
KEDUDUKAN HUKUM ISBAT NIKAH LUAR NEGERI
}

\author{
Ramdani Wahyu S. \\ Fakultas Syari'ah dan Hukum UIN Sunan Gunung Djati Bandung \\ Email: 124md4ni@gmail.com
}

\begin{abstract}
This paper is motivated by the number of Indonesian Workers (TKI) who work abroad to get married in Sirri, some of them occurred in Malaysia. Based on this background, the authors interested in explaining the legal position validation of marriage in outside the country. That is the legal basis for the implementation of validation of marriage outside the country, referring to the legislation, ranging from generalist like regulations of Law Number 48 Of 2009 about The Judicial Authorities of clause 60B and Law about Religious Courts, as well as the rule of lex specialist like Circular Supreme Court Number 10 Of 2010, appendix B SK Supreme Court Nomor 084/KMA/ SK/V/2011 on Permit Session Establishment Marriage (isbat nikah/validation of marriage) in The embassies of the Republic of Indonesia. procedures of case examination about validation of marriage in outside the country followed the procedural law applicable in the Religious Court, whereas KUA which the authorities listed about validation of marriage in outside the country is PPN (The Registrar of Marriage) located in The embassies of the Republic of Indonesia in each country.
\end{abstract}

\begin{abstract}
Abstrak
Tulisan ini dilatarbelakangi dengan banyaknya Tenaga Kerja Indonesia (TKI) yang bekerja di luar negeri melangsungkan pernikahan secara sirri, beberapa diantaranya terjadi di Malaysia. Dari latar belakang ini, penulis tertarik untuk menjelaskan kedudukan hukum isbat nikah di luar negeri. Bahwa yang menjadi dasar hukum pelaksanaan isbat nikah di luar negeri ini, mengacu kepada peraturan perundangundangan, mulai dari peraturan yang generalis seperti Undang-Undang Nomor 48 Tahun 2009 tentang kekuasaan kehakiman pasal 60B dan Undang-Undang tentang Peradilan Agama, serta peraturan yang lex spesialis seperti Surat Edaran Ketua Mahkamah Agung Nomor 10 Tahun 2010, lampiran B SK Mahkamah Agung Nomor 084/KMA/SK/V/2011 tentang ljin Sidang Penetapan Nikah (Isbat Nikah) di Kantor Perwakilan RI. Prosedur pemeriksaan perkara isbat nikah di luar negeri mengikuti hukum acara yang berlaku di Pengadilan Agama, sedangkan KUA yang berwenang mencatatkan isbat nikah di Luar Negeri adalah PPN (Pejabat Pencatat Nikah) yang berkedudukan di Kantor Perwakilan RI pada setiap negara.
\end{abstract}

Kata Kunci:

Isbat Nikah, Pejabat Pencatat Nikah, Pengadilan Agama

\section{A. Pendahuluan}

Isbat nikah luar negeri merupakan kebijakan justice for all Mahkamah Agung. Sejak lima tahun belakangan ini, Mahkamah Agung telah menegaskan pentingnya akses ke pengadilan bagi masyarakat yang mengalami kesulitan, baik secara ekonomis maupun geografis, karena fakta menunjukkan masya- rakat miskin dan masyarakat yang berdomisili jauh dari kantor pengadilan menghadapi kesulitan dan hambatan yang sangat serius untuk dapat mengakses pengadilan, terutama berkaitan dengan biaya perkara dan biaya transportasi, sehingga tidak sedikit masyarakat dan warga negara RI yang termarjinalkan, bahkan sama sekali tidak mem- 
peroleh perlindungan hukum dan keadilan yang sewajarnya.

Atas kenyatan itulah kebijakan justice for all tersebut ditungkan dalam Surat Edaran Nomor 10 tahun 2010 tertanggal 30 agustus 2010 tentang Pedoman Pemberian Bantuan Hukum yang bertujuan antara lain; membantu masyarakat pencari keadilan yang tidak mampu secara ekonomis dalam menjalankan proses hukum di pengadian, meningkatkan akses terhadap keadilan, meningkatkan kesadaran dan pengetahuan masyarakat tentang hukum melalui penghargaan, pemenuhan dan perlindungan hukum terhadap hak dan kewajibannya dan memberikan pelayanan prima kepada masyarakat pencari keadilan.'

Beberapa fakta menunjukkan bahwa para TKI yang bekerja di luar negeri melangsungkan pernikahan secara sirri. Beberapa diantaranya terjadi di Malaysia. Oleh karena itu, KBRI di Kuala Lumpur merencanakan program Isbat Nikah. ${ }^{2}$ Pemikahan sirri yang terjadi di luar negri, relatif banyak dilakukan oleh Tenaga Kerja Indonesia (TKI). Hal inilah yang memicu Mahkamah Agung melalui Pengadilan Agama Jakarta Pusat melakukan sidang keliling ke Malaysia pada tahun 2011 dan 2012. Program ini dilakukan bekerjasama dengan Kementerian Luar Negeri melalui KBRI di luar negeri, khusus untuk perkara permohonan isbat nikah. Sidang keliling di luar negeri atas permohonan isbat nikah ini umumnya dimohonkan oleh pasangan TKI yang beragama Islam untuk mengesahkan perkawinannya yang sebelumnya pernah menikah sah secara agama, tetapi belum memiliki buku nikah karena perkawinannya belum tercatat di Kantor Urusan Agama. Mereka umumnya kesulitan dari segi transportasi dan ekonomi untuk mengesahkan perkawinannya di Indonesia (kondisi geografis yang sangat jauh). Selain alasan itu, kadang-kadang ditemukan juga adanya ham-

\footnotetext{
1 Masrum M Noor, Penetapan Pengesahan Perkawinan (Isbat Nikah) Bagi Warga Negara Indonesia di Luar Negeri, Makalah disampaikan dalam loka karya di Kinabalu, Malaysia, pada tanggal 11-14 Mei 2011.

2 H.U Kompas, Isbat Nikah Solusi Nikah Sirri TKI di Malayasia, dalam http://luar-negeri. Kompasiana. com/2013/01/19, diakses tanggal 19 Juni, 2014.
}

batan dari perusahaan untuk tidak meninggalkan tempat kerja mengingat target produktivitas dan beban kerja tinggi dan teramat ketat.

Ketika terjadi benturan dengan masalah keimigrasian, mereka yang telah terlanjur menikah akan kebingungan. Karena salah satu syarat bagi sebuah keluarga untuk mendapatkan kelengkapan dokumen keimigrasian adalah adanya bukti akta nikah. Apabila mereka tidak mempunyai buku akta nikah, maka akan sulit untuk mendapatkan paspor dan visa sebagai bukti izin tinggal. Tidak jarang mereka ketidakutan, dan ketika tertangkap mereka akan dideportasi tanpa ampun. Akibat dari tidak memiliki bukti izin tinggal tersebut, beberapa tahun belakangan ini ribuan TKI dipulangkan ke Indonesia dengan kondisi menyedihkan. Mereka pulang dengan kondisi tidak terhormat, dan tidak dihargai hak-hak asasinya. ${ }^{3}$

Bertempat di kantor Konsulat Jenderal RI Kota Kinabalu pada tahun 2011, 670 pasangan suami-istri yang memohon isbat nikah telah disidangkan oleh dua majelis hakim agama. Dari 670 permohonan itu, tidak semua dikabulkan untuk disahkan perkawinannya. Hanya 635 permohonan yang disahkan, sisanya ditunda karena masih diperiksa kelengkapan keabsahan dokumendokumennya. ${ }^{4}$

Beberapa KBRI di beberapa negara melakukan hal yang sama, yaitu melangsungkan pelaksanaan Isbat Nikah di Luar Negeri sehubungan banyak terdapat warga negara Indonesia yang bertempat tinggal di sana tidak memiliki dokumen hukum yaitu akta pernikahan. Sebagaimana di jelaskan di atas, akta nikah ini sangat penting bagi kehidupan seseorang karena tanpa akta nikah, seorang WNI yang berada di luar negeri tidak akan mampu mengurus dokumen lainnya seperti paspor, ijin tinggal, visa dan sebagainya.

3 Muhtarudin Bahroen, Legalisasi Nikah Sirri Melalui Isbat Nikah menurut Kompilasi Hukum Islam, dalam Jurnal Diskursus Islam Volume 1 Nomor 2, Agustus 2013.

4 http://www.badilag.net/lipntan-rakernas-2011/434-berita-kegiatan/8594-hakim-agamalayani-sidangIsbat-di-luar-negeri-3009.html, diakses tanggal 28 April 2012. 
Secara hukum pelaksanaan isbat nikah di luar negeri dapat dikaji mengenai kedudukan hukumnya, yaitu apa dasar kebolehan isbat nikah di luar negeri? bagaimana prosedur acara pemeriksaannya, KUA mana yang berwenang mencatatkan penetapan isbat nikah tersebut dan bagaimana kewenangan relatif Pengadilan Agama yang jangkauannya sampai ke luar negeri ?.

Beberapa masalah hukum inilah yang kemudian menjadi fokus kajian dalam karya tulis ilmiah ini.

\section{B. Dasar Hukum Isbat Nikah Luar Negeri}

Pelaksanaan isbat nikah di luar negeri yang bertempat di KBRI memiliki dasar hukum sebagai berikut:

1. Pasal 56 ayat (1) Undang-Undang Nomor 48 Tahun 2009 tentang Kekuasaan Kehakiman dan pasal 60B UndangUndang Nomor 50 Tahun 2009 tentang Perubahan ke Dua atas Undang-Undang Nomor 7 Tahun 1989 tentang Peradilan Agama: "Setiap orang yang tersangkut perkara berhak memperoleh bantuan hukum";

2. Pasal 49 Undang-Undang Nomor 7 Tahun 1989 tentang Peradilan Agama sebagaimana telah diubah dengan UndangUndang Nomor 3 Tahun 2006 dan Undang-Undang Nomor 50 Tahun 2009 beserta penjelasannya;

3. Surat Edaran Ketua Mahkamah Agung nomor 10 tahun 2010, lampiran B tentang Pedoman Pemberian Bantuan Hukum di lingkungan Peradilan Agama;

4. Keputusan Bersama Ketua Muda Urusan Lingkungan Peradilan Agama dan Sekretaris Mahkamah Agung RI nomor 04/TUADA-AG/II/2011 dan nomor 020/SEK/SK/II/2011 tentang Petunjuk Pelaksanaan Surat Edaran Mahkamah Agung RI Nomor 10 tahun 2010 tentang Pedoman Bantuan Hukum Lampiran B;

5. Undang-Undang Nomor 22 Tahun 1946 tentang Pencatatan Nikah, Talak dan Rujuk;

6. Peraturan Menteri Agama RI nomor 11 tahun 2007 tentang Pencatatan Nikah;

7. Pasal 7 Kompilasi Hukum Islam (KHI), tentang Isbat Nikah;
8. Keputusan Ketua mahkamah Agung RI nomor KMA/032/SK/IV/2006, tanggal 4 April 2006, tentang Pemberlakuan Buku II; Pedoman Pelaksanaan Tugas dan Administrasi Pengadilan; dan

9. Rumusan hasil komisi II Urusan Lingkungan Peradilan Agama pada Rapat Kerja Nasional Mahkamah Agung Rl, tanggal 13 Oktober 2010, di Balikpapan angka 11; "Untuk membantu tenaga kerja wanita/tenaga kerja Indonesia yang menghadapai masalah hukum diluar negeri khususnya yang menyangkut masalah bidang perkawinan, perlu terobosan mengenai kemungkinan untuk melaksanakan pemeriksaan/persidangan perkara isbat nikah di Kedutaan Besar Indonesia termasuk pembiayaannya".

Dasar hukum di atas belum mencerminkan pengaturan yang jelas mengenai pelaksanaan isbat nikah di luar negeri. Tetapi dasar acuannya diatur oleh Surat Keputusan MARI Nomor 084/KMA/SK/V/2011 yang isinya Mahkamah Agung RI memberi izin bagi Pengadilan Agama Jakarta Pusat sebagai satu-satunya Pengadilan yang berwenang untuk melakukan sidang pengesahan perkawinan (Isbat Nikah) di Kantor Perwakilan Republik Indonesia. Sehingga karena kewenangannya bersidang di Luar negeri ini, Pengadilan Agama Jakarta Pusat kerap dijuluki Pengadilan Internasional.

Kemudian SK Mahkamah Agung RI tersebut ditindaklanjuti oleh Pengadilan Tinggi Agama Jakarta melalui Keputusannya Nomor W9-A/509/Hk.03.5/11/2012 tentang Petunjuk Pelaksanaan Sidang Pengesahan Perkawinan (Isbat Nikah) di Kantor Perwakilan RI, yang kemudian petunjuk pelaksanaan PTA Jakarta itu dijabarkan lagi oleh Ketua Pengadilan Agama Jakarta Pusat secara lengkap meliputi penyusunan tim pelaksana sidang Isbat Nikah, biaya perkara Isbat Nikah, dan Pedoman teknis sidang Isbat Nikah di luar negeri. ${ }^{5}$

Dasar dikeluarkannya SK MARI tersebut yaitu karena adanya beberapa persoalan

5 Aam Hamidah, Menakar Yuriditas Isbat Nikah di Luar Negeri (Suatu Catatan), Makalah dalam www.badilag.net, diakses tanggal 28 April 2012. 
yang muncul dalam kehidupan perkawinan para WNI dan TKI di luar negeri, yaitu:

1. Bahwa tidak sedikit pasangan suami istri WNI yang melangsungkan perkawinan menurut syariat Islam dihadapan para imam masjid atau ulama setempat dan perkawinannya tersebut tidak dapat dicatatkan atau didaftarkan di kantor perwakilan RI setempat, karena di kanor perwakilan RI setempat tersebut belum memiliki PPN/Penghulu;

2. Bahwa dengan kondisi tersebut di atas kebanyakan keluarga WNI di luar negeri tidak mempunyai kepastian hukum, bukan lantaran yang bersangkutan tidak taat hukum yang berlaku di negara Republik Indonesia, tetapi lantaran lembaga yang bertanggung jawab tentang hal tersebut tidak tersedia di perwakilan RI setempat;

3. Bahwa banyak pasangan suami istri yang tidak memiliki akta nikah/buku kutipan akta nikah karena akta nikah/buku kutipan akta nikahnya hilang atau rusak, sedangkan pengganti dari akta nikah/buku kutipan akta nikah dari KUA tempat tinggalnya di Indonesia hanya berupa duplikat akta nikah yang oleh pihak luar negeri tidak dianggap sebagai bukti sahnya suatu perkawinan, sehingga yang bersangkutan tetap memerlukan akta nikah/buku kutipan akta nikah, namun akta nikah dan kutipannya tersebut baru dapat diberikan oleh PPN perwakilan RI setelah menunjukkan penetapan isbat nikah dari Pengadilan Agama;

4. Bahwa di beberapa perwakilan RI yang telah memiliki PPN/Penghulu masih banyak Pasangan suami istri WNI yang menikah sebelum adanya PPN/penghulu di perwakilan tersebut, sehingga masih banyak pasangan suami istri yang tidak memiliki akta nikah atau buku kitipan akta nikah, padahal yang bersangkutan sangat membutuhkan akta nikah/buku kutipan akta nikah sebagai satu-satunya alat bukti sahnya perkawinan mereka, namun akta/buku kitipan akta nikah tersebut tidak dapat diperoleh tanpa terlebih dahulu menunjukkan penetapan isbat nikah dari Pengadilan Agama;
5. Bahwa banyak anak-anak dari pasangan suami istri WNI di luar negeri yang kehilangan hak-hak sipil mereka, terutama selama mereka tinggal bersama ayah ibunya di luar negeri, karena orang tua mereka tidak mampu menunjukkan akta nikah/buku kutipan akta nikah yang akan dijadikan dasar bagi anak-anak tersebut untuk mendapatkan dana pendidikan, kesehatan dan lain-lain dari negara setempat, sedangkan untuk mendapatkan akta nikah/buku kutipan akta nikah yang bersangkutan harus terlebih dahulu memperoleh penetapan isbat nikah dari Pengadilan Agama; dan

6. Bahwa untuk memperoleh penetapan pengesahan isbat nikah dari Pengadilan Agama hingga saat ini tidak ada ketentuan pasti; pengadilan manakah yang mempunyai kewenangan mengadili perkara isbat nikah atas perkawinan yang dilangsungkan di luar negeri tetapi tidak tercatat/terdaftar baik di PPN perwakilan RI maupun di KUA Indonesia.

Pada hakekatnya kebijakan strategis Mahkamah Agung RI melalui SK Nomor 084/KMA/SK/V/2011 tentang ljin Sidang Penetapan Nikah (Isbat Nikah) di Kantor Perwakilan RI adalah demi berjalannya peradilan yang mudah diakses oleh warga negara Indonesia dimanapun ia berada, utamanya masyarakat pencari keadilan yang berada dalam kondisi ekonomi yang tidak mampu dan bertempat tinggal di wilayah yang jauh dan sulit untuk menjangkau kantor pengadilan, guna mendapatkan pelayanan hukum dan memperoleh keadilan.

Warga negara Indonesia yang berada di luar negeri mungkin tidak semuanya dalam keadaan tidak mampu, namun pasti akan memerlukan biaya yang sangat tinggi dan membutuhkan waktu yang cukup lama, jika ingin mengurus isbat nikahnya di Pengadilan Agama, sementara sangat tidak mudah untuk meninggalkan pekerjaan dan usahanya di luar negeri, baik dari segi administrasi perjalanannya maupun kontrak kerjanya dengan pihak asing dan lain-lain yang berkaitan dengan keberadaan dan kehidupannya di luar negeri. 
Pertimbangan-pertimbangan seperti inilah yang mendorong Mahkamah Agung untuk memberikan perlindungan dan kepastian hukum bagi keluarga WNI/TKI di luar negeri serta demi meningkatkan akses terhadap keadilan kepada segenap warga negara Indonesia, maka Pengadilan Agama Jakarta Pusat dapat diberi ijin melaksanakan sidang pengesahan isbat nikah di Kantor Perwakilan Republik Indonesia.

Dengan demikian, dasar hukum pelaksanaan isbat nikah di luar negeri yang paling teknis adalah Surat Keputusan Mahkamah Agung RI Nomor 084/KMA/SK/V/2011 tentang Ijin Sidang Penetapan Nikah (Isbat Nikah) di Kantor Perwakilan RI yang dilaksanakan oleh Pengadilan Agama Jakarta Pusat. Sekalipun dalam ranah tata hukum perundangundangan kedudukan SK tersebut merupakan regulasi internal, namun dalam diktum pertimbangan dan keputusannya mengacu pada peraturan perundang-undangan yang lebih tinggi sehingga SK tersebut merupakan penjabaran atau penafsiran di dalam rangka pelaksanaan asas kepastian dan keadilan bagi masyarakat yang sulit menjangkau pengadilan. Pada tahap ini, SK MA tersebut tidak dipandang mengandung problem hukum.

\section{Prosedur Pemeriksaan Perkara Isbat Nikah}

Surat Keputusan Mahkamah Agung RI Nomor 084/KMA/SK/V/2011 tentang ljin Sidang Penetapan Nikah (Isbat Nikah) di Kantor Perwakilan RI mengamanatkan dalam diktum penetapan nomor dua bahwa "sidang pengesahan perkawinan (isbat nikah) sebagaimana tersebut dalam diktum pertama, dilaksanakan sesuai ketentuan hukum acara".

Mencermati hal ini, sesungguhnya tidak banyak yang berubah mengenai proses pemeriksaan pengesahan isbat nikah dengan pemeriksaan isbat di pengadilan. Secara teknis dapat digambarkan prosedur pendaftaran, pemeriksaan dan penetapan isbat nikah di luar negeri sebagai berikut:

1. Di Kantor Perwakilan

a) Petugas yang ditunjuk oleh Kantor Perwakilan RI di Luar Negeri menerima permohonan isbat nikah; b) Petugas yang ditunjuka oleh Kantor Perwakilan RI di luar negeri meneliti berkas perkara permohonan;

c) Petugas yang ditunjuka oleh Kantor Perwakilan RI di luar negeri menerima biaya perkara dari pemohon sebagai PNBP;

d) Petugas yang ditunjuka oleh Kantor Perwakilan RI di luar negeri Mencatat perkara dalam buku bantu register perkara permohonan;

e) Petugas yang ditunjuka oleh Kantor Perwakilan RI di luar negeri menyetorkan biaya perkara kepada Pengadilan Agama Jakarta Pusat melalui rekening Bank Syariah Mandiri, No Rek: 0010176322;

f) Petugas yang ditunjuka oleh Kantor Perwakilan RI di luar negeri meneruskan berkas perkara yang telah dilengkapi surat pengantar kwitansi tanda setor biaya perkara kepada Ketua Pengadilan Agama Jakarta Pusat;

g) Petugas yang ditunjuka oleh Kantor Perwakilan RI di luar negeri mengumumkan adanya permohonan isbat nikah di Kantor Perwakilan RI; dan

h) Petugas yang ditunjuka oleh Kantor Perwakilan RI di luar negeri menyiapkan ruangan untuk persidangan.

2. Di Pengadilan Agama Jakarta Pusat

a) Petugas Meja I menerima berkas perkara dari perwakilan RI;

b) Petugas Meja I membuat SKUM untuk tiap-tiap berkas sejumlah Rp41.000,00

c) Petugas Meja I menyerahkan berkas perkara yang telah di lengkapi SKUM kepada Kasir Pengadilan Agama Jakarta Pusat;

d) Kasir mencatat biaya perkara ke dalam buku jurnal biaya perkara;

e) Kasir menyerahkan berkas perkara kepada Meja II;

f) Petugas Meja II menerima berkas perkara dari Kasir Petugas meja II 5 menit;

g) Petugas Meja II Mencatat/mendaftar perkara ke dalam buku register induk perkara permohonan Petugas meja II;

h) Petugas Meja II meneruskan berkas perkara kepada Ketua Pengadilan Agama Jakarta Pusat dengan menyertakan 
blangko PMH, PHS, Penunjukan PP dan JS/JSP melalui Panitera;

i) Panitera menunjuk PP dan JS/JSP;

j) Panitera menyerahkan berkas perkara kepada Ketua Pengadilan Agama Jakarta Pusat;

k) Ketua membuat PMH;

l) Ketua menyerahkankan berkas perkara kepada PP;

m) Panitera Pengganti memberitahukan PMH kepada ketua majelis hakim;

n) Ketua Majelis Hakim memerintahkan JS/JSP untuk mengumumkan adanya permohonan isbat nikah di papan pengumuman Pengadilan Agama Jakarta Pusat;

o) Juru Sita/Juru Sita Pengganti melaksanakan pengumuman tentang adanya permohonan isbat nikah;

p) Ketua Majelis membuat PHS dan memerintahkan kepada JS/JSP untuk memanggil Pemohon;

q) Juru Sita/Juru Sita Pengganti memanggil Pemohon melalui Direktorat Jenderal Protokol dan Konsuler Kemenlu;

r) Juru Sita/Juru Sita Pengganti mempersiapkan Perjalanan majelis hakim ke perwakilan RI; dan

s) Panitera mengurus dokumen dan biaya perjalanan majelis hakim.

3. Sidang di Perwakilan RI

a) Juru Sita/Juru Sita Pengganti menyiapkan kelengkapan persidangan di perwakilan RI;

b) Juru Sita/Juru Sita Pengganti dan Panitera Pengganti menetapkan urutan sidang isbat nikah yang akan disidangkan;

c) Majelis Hakim melaksanakan persidangan mulai pukul 09.00 s/d 18.00;

d) Panitera Pengganti menyelesaikan pengetikan penetapan isbat nikah (minutasi); dan

e) Juru Sita/Juru Sita Pengganti menyerahkan amar penetapan isbat nikah kepada PPN.

4. PPN Perwakilan RI Setempat

a) PPN Perwakilan RI setempat menerima amar penetapan dari JS/JSP; b) PPN Perwakilan RI setempat menerbitkan akta nikah/buku kutipan akta nikah;

c) PPN Perwakilan RI setempat menyerahkan buku kutipan akta nikah kepada pemohon; dan

d) PPN Perwakilan RI setempat menyerahkan rangkap ke 2 akta nikah kepada PP untuk disimpan di Pengadilan Agama Jakarta Pusat (www.pa-jakartapusat.go.id).

Uraian di atas merupakan Standar Operating Prosedur yang dimiliki oleh Pengadilan Agama Jakarta Pusat mengenai tahapan persiapan, pelaksanaan sidang dan pelaksanaan penetapan/putusan pengadilan isbat nikah. Namun demikian, berdasarkan data dari beberapa Kantor Perwakilan RI di luar negeri ditemukan bahwa proses pemeriksaan isbat nikah persis sama dengan hukum acara pada saat pemeriksaan isbat nikah di pengadilan. Hal ini bisa disimak pada beberapa web KBRI yang ada di luar negeri mengenai proses pemeriksaan isbat nikah. Salah satunya prorses pemeriksaan isbat nikah pada Kantor Perwakilan RI di HoustonTexas.

Proses pengajuan dan pemeriksaan perkara isbat nikah yang diumumkan pada Kantor Perwakilan RI di Houston-Texas Amerika serikat sebagai berikut:

1. Permohonan isbat nikah dapat dilakukan oleh kedua suami istri atau salah satu dari suami istri, anak, wali nikah dan pihak lain yang berkepentingan dengan perkawinan tersebut kepada Pengadilan Agama dalam wilayah hukum pemohon bertempat tinggal, dan permohonan isbat nikah harus dilengkapi dengan alasan dan kepentingan yang jelas serta konkrit;

2. Proses pemeriksaan permohonan isbat nikah yang diajukan oleh kedua suami istri bersifat voluntair, produknya berupa penetapan. Jika isi penetapan tersebut menolak permohonan isbat nikah, maka suami istri bersama-sama atau suami, istri masing-masing dapat mengajukan upaya hukum kasasi;

3. Proses pemeriksaan permohonan isbat nikah yang diajukan oleh salah seorang suami atau istri bersifat kontensius de- 
ngan mendudukkan istri atau suami yang tidak mengajukan permohonan sebagai pihak termohon, produknya berupa putusan dan terhadap putusan tersebut dapat diajukan upaya hukum banding dan kasasi;

4. Jika dalam proses pemeriksaan permohonan isbat nikah dalam angka (2) dan (3) tersebut di atas diketahui bahwa suaminya masih terikat dalam perkawinan yang sah dengan perempuan lain, maka istri terdahulu tersebut harus dijadikan pihak dalam perkara. Jika pemohon tidak mau merubah permohonannya dengan memasukkan istri terdahulu sebagai pihak, permohonan tersebut harus dinyatakan tidak dapat diterima;

5. Permohonan isbat nikah yang dilakukan oleh anak, wali nikah dan pihak lain yang berkepentingan harus bersifat kontensius, dengan mendudukkan suami dan istri dan/atau ahli waris lain sebagai termohon;

6. Suami atau istri yang telah ditinggal mati oleh istri atau suaminya, dapat mengajukan permohonan isbat nikah secara kontensius dengan mendudukkan ahli waris lainnya sebagai pihak termohon, produknya berupa putusan dan atas putusan tersebut dapat diupayakan banding dan kasasi;

7. Dalam hal suami atau istri yang ditinggal mati tidak mengetahui ada ahli waris lain selain dirinya, maka permohonan isbat nikah diajukan secara voluntair, produknya berupa penetapan. Jika permohonan tersebut ditolak, maka pemohon dapat mengajukan upaya hukum kasasi;

8. Orang lain yang mempunyai kepentingan dan tidak menjadi pihak dalam perkara permohonan isbat nikah tersebut dalam angka (2) dan (6), dapat melakukan perlawanan kepada Pengadilan Agama yang memutus, setelah mengetahui ada penetapan isbat nikah;

9. Orang lain yang mempunyai kepentingan dan tidak menjadi pihak dalam perkara permohonan isbat nikah tersebut dalam angka (3), (4) dan (5), dapat mengajukan intervensi kepada Pengadilan Agama yang memeriksa perkara isbat nikah tersebut selama perkara belum diputus;

10. Pihak lain yang mempunyai kepentingan hukum dan tidak menjadi pihak dalam perkara permohonan isbat nikah tersebut dalam angka (3), (4) dan (5), sedangkan permohonan tersebut telah diputus oleh Pengadilan Agama, dapat mengajukan gugatan pembatalan perkawinan yang telah disahkan oleh Pengadilan Agama tersebut;

11. Ketua majelis hakim 3 hari setelah menerima Penetapan Majelis Hakim (PMH), membuat Penetapan Hari Sidang (PHS) sekaligus memerintahkan jurusita pengganti untuk mengumumkan permohanan pengesahan nikah tersebut 14 hari terhitung sejak tanggal pengumuman pada media massa cetidak atau elektronik atau sekurang-kurangnya diumumkan pada papan pengumuman Pengadilan Agama;

12. Majelis hakim dalam menetapkan hari sidang paling lambat 3 hari setelah berakhirnya pengumuman. Setelah hari pengumuman berakhir, Majelis Hakim segera menetapkan hari siding; dan

13. Untuk keseragaman, amar pengesahan nikah berbunyi sebagai berikut:

- Menyatakan sah perkawinan antara ................. dengan ........... yang dilaksanakan pada tanggal ................... di ..............".

- Membebankan kepada pemohon biaya sebesar Rp116.000,00 (USD......)

Jelaslah bahwa pemeriksaan perkara isbat nikah di luar negeri mengikuti hukum acara yang berlaku sebagaimana pemeriksaan di Pengadilan Agama di Indonesia. Yang membedakan adalah tempat sidang yang dalam hal ini bertempat di Kantor Perwakilan RI di luar negeri. Pemeriksaan perkara isbat nikah sekalipun bertempat di luar negeri, dengan mellihat SOP dan tahapan pemeriksaan sebagaimana dinyatakan dalam pemberitahuan sidang isbat nikah pada Kantor Perwakilan RI di luar negeri menunjukkan bahwa pemeriksaan isbat nikah telah sah secara hukum.

\section{KUA yang Berwenang Mencatatkan Isbat Nikah di Luar Negeri}


Kementerian Agama Republik Indonesia telah mengeluarkan Peraturan Menteri Agama No. 11 tahun 2007, yang di dalamnya terdapat Pasal yang memuat tentang Pencatatan Nikah yaitu dalam Bab XI Pasal 28 yang berbunyi: "Pencatatan nikah bagi warga negara Indonesia yang ada di luar negeri dilakukan sebagaimana diatur dalam Keputusan Bersama Menteri Agama Republik Indonesia dan Menteri Luar Negeri Republik Indonesia No. 589 tahun 1999 dan Nomor 182/OT/X/99/01 tahun 1999 tentang Petunjuk Pelaksanaan Perkawinan warga Negara Indonesia di Luar Negeri".

Sedangkan ternyata, bahwa di Konsulat Jenderal RI terdapat bidang atau bagian dari tata kerja Konsulat Jendral yang di dalamnya ada bagian yang bertugas menangani pencatatan nikah yang dilaksanakan di wilayahnya tersebut, sehingga dengan demikian apabila pernikahannya sudah dinyatakan sah melalui sidang isbat nikah oleh Majelis Hakim PA Jakarta Pusat, maka selanjutnya penetapan tersebut dapat dicatatkan oleh PPN yang terdapat di Konsulat Jendral RI tersebut.

Setiap Kantor Perwakilan RI di luar negeri pada dasarnya memiliki PPN (Pejabat Pencatat Nikah). Oleh karena itu, setiap WNI atau TKI yang berada di luar negeri semestinya mencatatkan perkawinannya ke Kantor Perwakilan RI dimana mereka tinggal. Kalaupun mereka tidak mencatatkan perkawinannya ke PPN di Kantor Perwakilan RI, maka mereka wajib mengisbatkan dulu perkawinannya di Kantor Perwakilan RI tersebut. Keberadaan PPN pada setiap Kantor Perwakilan RI di luar negeri didasarkan pada KMA No. 463 Th. 2000 tentang pendelegasian wewenang pengangkatan PPN di luar negeri. Dalam KMA tersebut dinyatakan bahwa Menteri Agama mendelegasikan wewenang kepada Perwakilan RI di luar negeri untuk mengangkat dan mmberhentikan PPN (Pegawai Pencatat Nikah) pada perwakilan RI di wilayahnya. PPN merupakan pejabat yang membidangi masalah kekonsuleran pada Perwakilan RI di Luar Negeri dan bertindak sebagai penghulu. Apabila pejabat tersebut beragama selain agama Islam, maka Kepala Perwakilan RI mengangkat pejabat lain yang beragama Islam sebagai PPN.
Dengan adanya tiga regulasi dari pemerintah, yaitu Keputusan Bersama Menteri Agama Republik Indonesia dan Menteri Luar Negeri Republik Indonesia No. 589 tahun 1999 dan Nomor 182/OT/X/99/01 tahun 1999 tentang Petunjuk Pelaksanaan Perkawinan warga Negara Indonesia di Luar Negeri, KMA Nomor 463 Tahun 2000 tentang pendelegasian wewenang pengangkatan PPN di luar negeri dan PMA Nomor 11 Tahun 2007 menunjukkan bahwa yang berwenang mencatatkan perkawinan di luar negeri adalah PPN pada Kantor Perwakilan RI di Luar Negeri. Berdasarkan regulasi tersebut, setiap WNI yang berada di luar negeri dapat dengan mudah mencatatkan perkawinannya di Kantor Perwakilan RI. Jikapun ternyata masih ada WNI atau TKI yang menikah tanpa dicatat, maka ia harus melakukan pengesahan nikah melalui Pengadiilan Agama Jakarta Pusat dengan catatan harus dilihat secara cermat alasan pengajuan isbat tersebut supaya terhindari dari upaya penyelundupan hukum.

\section{E. Pengadilan yang Berwenang Memerik- sa Isbat Nikah di Luar Negeri}

Sampai saat ini memang belum ada peraturan perundangan atau hukum acara yang mengatur tentang Pengadilan Agama mana yang berwenang untuk mengadili perkara isbat nikah atas pernikahan WNI muslim di luar negeri, akan tetapi terdapat beberapa pasal yang dapat dijadikan analog tentang penyelesaian sengketa keluarga $\mathrm{WNI}$ yang berdomisili di luar negeri tersebut, antara lain:

1. Pasal 66 ayat (4) Undang-Undang Nomor 7 Tahun 1989, tentang Peradilan Agama: "Dalam hal Pemohon dan Termohon bertempat kediaman di luar negri, maka permohonan diajukan di pengadilan yang daerah hukumnya meliputi tempat perkawinan mereka dilangsungkan atau Pengadilan Agama Jakarta Pusat"; dan

2. Pasal 73 ayat (3), Undang-Undang Nomor 7 Tahun 1989, tentang Peradilan Agama: "Dalam hal Penggugat dan Tergugat bertempat kediaman di luar negeri, maka gugatan diajukan kepada Pengadilan yang daerah hukumnya meliputi tempat 
perkawinan mereka dilangsungkan atau kepada Pengadilan Agama Jakarta Pusat".

Kedua pasal tersebut di atas mengatur tentang tempat mengajukan perkara talak dan atau cerai bagi WNI yang berdomisili di luar negeri, yakni dengan memberikan alternatif; dapat di ajukan di Pengadilan Agama tempat nikah atau di Pengadilan Agama Jakarta Pusat. Pilihan pertama tersebut tentu diberikan jika perkawinannya dahulu dilakukan di salah satu KUA di Indonesia. Bagaimanakah jika ternyata perkawinannya tersebut tidak dilakukan di Indonesia? Maka pastilah tidak ada lagi alternatif lain keculai perkara tersebut harus diajukan di Pengadilan Agama Jakarta Pusat.

Dalam perkembangan akhir-akhir ini ternyata telah makin efektif pelaksanaan Keputusan bersama Menteri Agama RI dan Menteri Luar Negeri RI tentang Pedoman Pelaksanaan Perkawinan WNI di Luar Negeri, sehingga telah begitu banyak pasangan suami istri WNI-WNI atau WNI-WNA yang telah memiliki akta nikah atau buku kutipan akta nikah yang dikeluarkan oleh PPN Perwakilan RI di luar negeri, jika pasangan tersebut ingin bercerai tentu juga tidak ada alternatif lain kecuali harus mengajukan perkaranya ke Pengadilan Agama Jakarta Pusat.

Dengan demikian dapat dipahami secara analog apabila perkawinan WNI yang dilaksanakan di luar negeri namun tidak tercatat di PPN perwakilan RI setempat, baik dengan alasan belum ada PPN di perwakilan tersebut atau karena keadaan yang memaksa sehingga tidak dapat mencatatkan perkawinannya di PPN perwakilan setempat atau karena PPN tidak mungkin menerbitkan akta nikah yang bersangkutan sebelum yang bersangkutan menunjukkan penetapan pengesahan perkawinannya (isbat nikah) dari pengadilan, atau karena alasan yang lainnya, maka yang bersangkutan harus mengajukan isbat nikahnya di Pengadilan Agama Jakarta Pusat.

Selain itu, penunjukan Pengadilan Agama Jakarta Pusat sebagai tempat diajukannya gugatan bagi WNI di luar negeri didasari pula oleh hasil rapat konsultasi yang diselenggarakan pada tanggal 29-30 April 2011 yang dihadiri para wakil dari Kementerian Luar Negeri RI, Kementerian Agama RI, Kementerian Hukum dan HAM RI serta Mahkamah Agung Rl tentang perkawinan dan pengesahan nikah (isbat nikah) bagi warga Negara Indonesia di luar negeri yang beragama Islam, telah bersepakat khusus dalam pengesahan nikah (isbat nikah) sebagai berikut :

1. Pengadilan Agama Jakarta Pusat dapat mengadakan sidang keliling untuk perkara isbat nikah (pengesahan nikah) di kantor perwakilan RI di luar negeri setelah mendapat izin dari Mahkamah Agung RI;

2. Pengadilan Agana Jakarta Pusat akan mengadakan sidang isbat nikah (pengesahan nikah) sesuai dengan hukum dan peraturan perundangan yang berlaku;

3. Perwakilan RI setempat bersedia menyiapkan ruangan sidang keliling sesuai standart ruang sidang Pengadilan Agama;

4. Kementerian luar negeri atau perwakilan RI setempat bertanggung jawab atas semua pembiayaan sidang keliling yang meliputi:

a) Transportasi, akomodasi dan hak-hak lainnya majelis hakim, (3 orang), panitera, dan jurusita;

b) Keperluan alat tulis persidangan; dan

c) Biaya pengurusan dokumen perjalanan bagi majelis hakim, panitera dan jurusita.

5. Kepada pemohon isbat nikah (pengesahan nikah) hanya dibebani biaya perkara sebanyak Rp41.000,00 sebagai biaya Penerimaan Negara Bukan Pajak (PNBP).

Pelaksanan sidang isbat di luar negeri bagi WNI/TKI dilaksanakan pada Kantor Perwakilan RI yang merupakan wilayah negara Republik Indonesia yang didalamnya berlaku hukum negara Republik Indonesia dan siapa saja yang berada di dalamnya atau di negara tersebut, maka ia berada di bawah perlindungan Negara Republik Indonesia, baik dalam hal perlindungan hukum, perlindungan keselamatan maupun perlindungan lainnya. Dalam hal perlindungan dari segi hukum keluarga, negara Indonesia telah memberikan solusi dengan mengangkat PPN di perwakilan RI, bahkan ada kemungkinan akan ditingkatkan menjadi atase agama dimasing- 
masing perwakilan, akan tetapi peraturan perundang-undangan Indonesia tidak membenarkan berdirinya sebuah peradilan di perwakilan tersebut.

Kedudukan KBRI atau Kantor Perwakilan RI di luar negeri pada dasarnya merupakan etalase negara RI yang berkedudukan di luar negeri. la merupakan wilayah hukum Republik Indonesia. Setiap negara asing yang memiliki hubungan diplomatik dengan Indonesia, maka Indonesia membuka kantor perwakilan utama di sana yang dikepalai oleh seorang duta besar.

Menurut Keputusan Presiden Republik Indonesia Nomor 108 Tahun 2003 Tentang Organisasi Perwakilan Republik Indonesia Di Luar Negeri pada pasal 4 menyatidakan bahwa Perwakilan Diplomatik mempunyai tugas pokok mewakili dan memperjuangkan kepentingan Bangsa, Negara, dan Pemerintah Republik Indonesia serta melindungi Warga Negara Indonesia, Badan Hukum Indonesia di Negara Penerima dan/atau Organisasi Internasional, melalui pelaksanaan hubungan diplomatik dengan Negara Penerima dan/atau Organisasi Internasional, sesuai dengan kebijakan politik dan hubungan luar negeri Pemerintah Republik Indonesia, peraturan perundang-undangan nasional, hukum Internasional, dan kebiasaan Internasional.

Pasal ini sekaligus menegaskan bahwa Orgasasi Perwakilan RI yang berada di negara asing memiliki tugas pokok mewakili dan memperjuangkan kepentingan nasional Indonesia di wilayah negara asing sehingga segenap WNI yang berada di sana menjadi bagian dari perlindungan Kantor Perwakilan RI.

Lebih lanjuut Pasal 5 Keputusan Presiden Republik Indonesia Nomor 108 Tahun 2003 menyatidakan bahwa untuk melaksanakan tugas pokok sebagaimana dimaksud dalam Pasal 4, Perwakilan Diplomatik menyelenggarakan fungsi:

1. Peningkatan dan pengembangan kerja sama politik dan keamanan, ekonomi, sosial dan budaya dengan Negara Penerima dan/atau Organisasi Internasional;

2. Peningkatan persatuan dan kesatuan, serta kerukunan antara sesama Warga Negara Indonesia di luar negeri;
3. Pengayoman, pelayanan, perlindungan dan pemberian bantuan hukum dan fisik kepada Warga Negara Indonesia dan Badan Hukum Indonesia, dalam hal terjadi ancaman dan/atau masalah hukum di Negara Penerima, sesuai dengan peraturan perundang-undangan nasional, hukum Internasional, dan kebiasaan Internasional;

4. Pengamatan, penilaian, dan pelaporan mengenai situasi dan kondisi Negara Penerima;

5. Konsuler dan protokol;

6. Perbuatan hukum untuk dan atas nama Negara dan Pemerintah Republik Indonesia dengan Negara Penerima;

7. Kegiatan manajemen kepegawaian, keuangan, perlengkapan, pengamanan internal Perwakilan, komunikasi dan persandian; dan

8. Fungsi-fungsi lain sesuai dengan hukum dan praktak Internasional.

Berdasarkan pasal 5 di atas, jelaslah bahwa salah satu fungsi perwakilan diplomatik di negara asing ialah memberikan layanan hukum apabila para WNI yang berada di luar negeri memerlukannya. Terkait dengan pelaksanaan isbat nikah di Kantor Perwakilan RI di luar negeri, dapat dinyatakan bahwa perwakilan diplomatik adalah wilayah hukum Indonesia sehingga apabila WNI yang ada di sana memerlukan akses hukum seperti memperoleh akses pengadilan untuk memperoleh akta nikah, maka pemerintah RI yang diwakili oleh Kantor Perwakilan Diplomatik di luar negeri akan memberikan fasilitas layanan hukum tersebut.

Dengan demikian, kewenangan relatif Pengadilan Agama Jakarta Pusat bukan hanya mewilayahi Jakarta Pusat saja, ia juga memiliki kewenangan relatif di luar negeri sebagaimana dinyatatan dalam undangundang. Sedangkan pengertian apakah negara seperti Malaysia, Saudi Arabia dan negara-negara lainnya sebagai tempat dilaksanakannya isbat nikah merupakan kewenangan Pengadilan Agama Jakarta Pusat untuk melangsungkannya ? Jawabannya tentu saja iya dengan memperhatikan bahwa tempat pelaksanaan Isbat Nikah tersebut di Wilayah RI yaitu di Kantor Perwakilan Republik Indonesia yang merupakan wilayah hukum 
RI sebagaimana dinyatakan dalam tugas pokok dan fungsi Perwakilan Diplomatik dalam Perpres Nomor 108 Tahun 2003 di atas. Lebih teknis lagi, regulasi mengenai wilayah hukum RI di negara asing yang menjadi kewenangan pemerintah terdapat pada Keputusan Menteri Luar Negeri Nomor SK.06/A/O/VI/2004/01 Tahun 2004 tentang Organisasi dan Tata Kerja Perwakilan RI di Luar Negeri.

\section{F. Kesimpulan}

Berdasarkan uraian di atas, dapat dikemukakan kesimpulan sebagai berikut:

1. Dasar hukum tentang pelaksanaan isbat nikah di luar negeri berdasarkan pada berbagai peraturan perundang-undangan mulai dari peraturan yang generalis seperti Undang-Undang Nomor 48 Tahun 2009 tentang Kekuasaan Kehakiman pasal $60 \mathrm{~B}$ dan Undang-Undang tentang Peradilan Agama, serta peraturan yang lex spesialis seperti Surat Edaran Ketua Mahkamah Agung nomor 10 tahun 2010, lampiran B SK Mahkamah Agung Nomor 084/KMA/SK/V/2011 tentang ljin Sidang Penetapan Nikah (Isbat Nikah) di Kantor Perwakilan RI. Peraturan yang generalis tersebut pada pokoknya meminta agar setiap warga negara memperoleh hak bantuan hukum sehingga dasar pelaksanaan isbat nikah di luar negeri menjadi legal. Demikian pula karena undangundang di atasnya membolehkan, maka aturan yang lex spesialis memerinci lebih tegas mengenai pelaksanaan isbat nikah tersebut;

2. Prosedur pemeriksaan perkara isbat nikah di luar negeri mengikuti hukum acara yang berlaku di Pengadilan Agama bahwa tahapan-tahapan pemeriksaan mulai pendaftaran, persidangan dan penetapan hukumnya harus mengikuti ketentuan hukum acara yang berlaku sebagaimana lazimnya dilaksanakan pemeriksaannya di Pengadilan Agama;

3. KUA yang berwenang mencatatkan isbat nikah di Luar Negeri adalah PPN (Pejabat Pencatat Nikah) yang berkedudukan di Kantor Perwakilan RI pada setiap negara asing. Hal ini disimpulkan dari peraturan mengenai hal tersebut sebagaimana ter- cantum di dalam tiga regulasi dari pemerintah, yaitu Keputusan Bersama Menteri Agama Republik Indonesia dan Menteri Luar Negeri Republik Indonesia No. 589 Tahun 1999 dan Nomor 182/OT/X/99/01 Tahun 1999 tentang Petunjuk Pelaksanaan Perkawinan warga Negara Indonesia di Luar Negeri, KMA Nomor 463 Tahun 2000 tentang pendelegasian wewenang pengangkatan PPN di luar negeri dan PMA Nomor 11 Tahun 2007; dan

4. Pengadilan yang berwenang memeriksa isbat nikah di luar negeri adalah Pengadilan Agama Jakarta Pusat berdasarkan pada Pasal 66 ayat (4) Undang-Undang Nomor 7 Tahun 1989, tentang Peradilan Agama dan Pasal 73 ayat (3), UndangUndnag Nomor 7 Tahun 1989 tentang Peradilan Agama. Ketentuan pada pasal tersebut pada pokoknya menyebutkan bahwa apabila Pemohon dan Termohon bertempat kediaman di luar negri, maka permohonan diajukan di pengadilan yang daerah hukumnya meliputi tempat perkawinan mereka dilangsungkan atau Pengadilan Agama Jakarta Pusat.

\section{Daftar Pustaka}

Bahroen, Muhtarudin. 2013. Legalisasi Nikah Sirri Melalui Isbat Nikah menurut Kompilasi Hukum Islam. dalam Jurnal Diskursus Islam Volume 1 Nomor 2, Agustus 2013.

Hamidah, Aam. t.th. Menakar Yuriditas Isbat Nikah di Luar Negeri (Suatu Catatan), Makalah dalam www.badilag.net, diakses tanggal 2 Maret 2015.

H.U Kompas. 2013. Isbat Nikah Solusi Nikah Sirri TKI di Malayasia, dalam http://luarnegeri. kompasiana.com, diakses tanggal 2 April 2015.

Inpres Nomor 1 Tahun 1991 tentang Penyebarluasan Kompilasi Hukum Islam. Jakarta: Departemen Agama.

Keputusan Presiden Republik Indonesia Nomor 108 tahun 2003 tentang Organisasi Perwakilan Republik Indonesia di Luar Negeri http://hukum. unsrat.ac.id/ pres/- 
keppres_108_2003.pdf, diakses tanggal 30 Maret 2015.

KMA Nomor 463 Tahun 2000 tentang Pendelegasian Wewenang Pengangkatan PPN di luar negeri, dalam http://sukabumikota.kemenag. go.id/file/dokumen/D000961.pdf, diakses tanggal 1 April 2015.

Masrum, M. Noor. 2011. Penetapan Pengesahan Perkawinan (Isbat Nikah) Bagi Warga Negara Indonesia Di Luar Negeri, Makalah disampaikan dalam loka karya di Kinabalu, Malaysia tanggal 11 - 14 Mei 2011.

Peraturan Menteri Agama Nomor 11 Tahun 2007 tentang Pencatatan Nikah, dalam http://www.kemenag.go.id/file/file/ ProdukHukum/apcw 135 7615662.pdf, diakses tanggal 1 April 2015.

Pemberitahuan Isbat Nikah, dalam http://www.indonesiahouston.net/uploads/file s /news/sidang_isbat_nikah, diakses tanggal 1 April 2015.
Suherman. 2012. Hakim agama Layani Sidang Isbat di Luar Negeri. dalam http://www.badilag.net/lipntan-rakernas-2011/, diakses tanggal 28 April 2012.

Standar Operasinal Prosedur Isbat Nikah di Luar Negeri, dalam www.pa-jakartapusat.go.id, diakses tanggal 1 April 2015.

Surat Keputusan Mahkamah Agung Nomor 084/KMA/SK/V/2011 tentang ljin Sidang Penetapan Nikah (Isbat Nikah) di Kantor Perwakilan RI, dalam www.mahkamahagung.go.id, diakses tanggal 1 April 2015.

Tim Redaksi Fokus Media. 1997. UndangUndang Nomor 7 Tahun 1989 tentang Peradiilan Agama. Jakarta: Fokus Media.

Tim Redaksi Fokus Media. 1997. UndangUndang Nomor 48 Tahun 2009 tentang Kekuasaan Kehakiman. Jakarta: Fokus Media. 